\title{
The Impact of the Advent of English in Primary Schools on the Development of College English in China
}

\author{
Jun Liu \\ College of Foreign Languages, North China Electric Power University \\ Zhuxinzhuang, Changping District, Beijing 102206, China \\ E-mail: liuj59@126.com \\ Zhongxin Dai \\ College of Foreign Languages, North China Electric Power University \\ Zhuxinzhuang, Changping District, Beijing 102206, China \\ E-mail: zhongxindai@126.com
}

Received: May 20, 2011 Accepted: May 27, 2011 doi:10.5539/hes.v1n1p105

\begin{abstract}
This article discusses the impact of the advent of primary English on the development of College English in China. The advent of English in primary schools as a teaching subject has brought about a downward shift of focus of the English education system in China. Basic English education will be accomplished in primary and secondary schools. The part of basic English education conventionally assumed by college English will be gone and in its place there will be various content-based English courses, bilingual courses and courses taught entirely in English on different disciplines relevant to the majors of college students.
\end{abstract}

Keywords: Primary English, College English, English education

In the year 2001, English entered primary schools as a compulsory teaching subject for the third-year pupils in China, and key schools were encouraged to teach English from the first-year. English as a compulsory subject in primary schools must affect the existing English education system in China. The focus of basic English education has shifted downward to primary and secondary schools, and college English, which had assumed part of the responsibility of basic English Education, has been forced to undergo corresponding reforms.

Ten years has passed since English entered primary schools as a teaching subject. Pupils who took English ten years ago have entered colleges or universities, and the impact of the advent of primary English has begun to express itself in college English education. It is high time that college English prepared itself for the problems and challenges. This article intends to discuss the impact of primary English on the development college English education in China.

\section{College English: from Basic English to Content-based English Courses}

In 2001, the Education Ministry promulgated the New English Curriculum (Experimental Version). The Curriculum follows the international practice of dividing the general objectives into different ability levels. The objectives of the English subject in primary, junior and senior middle schools are divided into nine levels of English proficiency. According to the Curriculum, by the end of Grade Six, the graduation year of primary schools, pupils have to meet the basic requirements for the second level of English proficiency; by the end of Grade Nine, the graduation year of junior middle schools, students must meet the basic requirements for the fifth level; senior middle school graduates are to meet the basic requirements for the eighth level, and excellent and brilliant graduates are expected to meet the basic requirements for the ninth level. (China Education Ministry, 2001, p.3) The objectives for senior middle school graduates are comparable to those of college English. Take the description of the eight level as an example, the objectives for listening proficiency are: Students can: (1) understand speakers' intentions and attitudes according to their stress and intonation, (2) understand and extract information and viewpoints from discussions and talks about familiar topics, (3) grasp the gist of the listening passage, (4) understand the topics or themes of English news on radio and television, and (5) understand indirect suggestions and advice. (China Education Ministry, 2001, p. 17) 
The Curriculum formally marked the incorporation of primary school English into China's English education system, and indicated the downward shift of focus of basic English education. In the previous English education system, the actual starting point of English teaching and learning is the junior high school, and the new starting point for the English education system is from the first or the third grade of primary schools. By lowering the focus of basic English education, the overall level of English education has been raised. The lowering of the focus of English Education involves the lowering of focus of College English, which implies that college teachers' tasks of teaching the advanced part of basic English will have to be shifted downward to senior middle school English teachers, and college English teachers are left to seek new tasks. The eight and ninth English proficiency levels that middle school graduates are required to meet are already enough for them to attend English lectures at the tertiary level. Therefore, the conventional missions assigned to college English teachers have come to an end, and the traditional college English courses are no longer necessary to college students. Then, what should college teachers do, and what should college students do in order to further improve their English?

First, teachers may choose to offer more elective courses. With the new level of the freshmen's English proficiency, the existing courses based on basic English knowledge and skills cannot meet the freshmen's needs. As a result of this, the Education Ministry drafted and issued College English Curriculum Requirements as guidelines on college English teaching. Colleges and universities are encouraged to offer such elective courses as advanced language skills, practical English, cultures of the English-speaking countries, and major-related English. This requires college English researchers and English curriculum designers to set up advanced curriculum for elective English courses in order to meet the students' needs in the new era.

English elective courses can be classified into three types. The first type includes major-oriented courses, such as Electricity English, Accounting English, Business English, Medical English, Computer English, etc.; the second embraces literature- or culture-oriented courses, such as American Short Stories, Bible Stories, English Poetry, Appreciation of Shakespeare's Works, Comparison of Chinese and Western Cultures, Classics of English Literature; and the third consists of language-oriented electives, such as Advanced English Reading and Writing, Advanced English Audio-Visual-Speaking, Practical English Lexicology, Translation Theory and Techniques, Comparative Study of English and Chinese Grammar, Selected Reading Materials from English Newspapers and Magazines, etc.

Second, bilingual courses are available for students. Bilingual courses are intended to orient students towards academic or professional English. Bilingual courses will gradually replace traditional knowledge- or skill-oriented courses, and students will enhance their English through these major- or content-oriented courses. The goal of bilingual courses is to cultivate a large number of talented graduates capable of effective communication in both Chinese and English on topics relevant to their specialities. Bilingual courses in the institutions of higher learning have initiated a new model of English teaching, which will eventually eliminate examination-targeted English teaching and learning. Although the current bilingual instruction is not without problems, it suits the needs for the globalization of higher learning.

In September 2004, Professor Zhenning Yang, the Nobel Prize winner in Physics, successfully offered a bilingual course, physics, to 130 freshmen at Tsinghua University. (Beijing Youth, 2004, September 16) The success of Professor Yang's bilingual physics course will be recorded, as a successful example, in the history of modern bilingual education. Admittedly, the proficiency of those high school graduates who were admitted to Tsinghua University was much higher than that of average high school graduates. We should also admit that it was certainly unthinkable 20 years ago even for Tsinghua University. We have every reason to believe that with the downward shift of focus of English education, with the gradual implementation of the New English Curriculum, and with encouragement and support from the government, bilingual courses will flourish and become popular.

The significance of the college English course in the whole curriculum of higher learning lies in its function of enhancing college students' basic English skills. Once students have developed these skills and are in a position to use English to further study courses in their specialities and enhance their English competence through these courses, the significance of the traditional college English course will be lost. The traditional college English curriculum will become an obstacle to the development of college English. However, the elimination of the uniformed traditional college English course does not mean the elimination of other forms of English courses, as we can see from what is discussed above. Because students differ in their English proficiency, and in their motivation for further English study, their needs differ. This requires the English courses to be open and flexible, meeting the different needs of the students.

Colleges and universities can set up English training centers, offering a variety of courses according to the needs of 
students, such as English tuition for those who need to improve their basic English skills, speaking, essay writing, translation, TOEFL, GRE, IELTS and other types of training courses. The popularity of the English training market outside colleges and universities shows that these trainings have met the various needs of the people. English training centers in colleges and universities can also compete with those training organizations and serve the society. Their participation in the competition will effectively regulate the English training market in China. Once the nation-wide examination for college English has been abandoned, English learning will be motivated by individual needs, and English teaching will become normal again. Otherwise, college English teaching will be examination-oriented, and real English learning occurs outside or after college English.

\section{The Goal of College English: the Cultivation of "Speciality + English" Graduates}

The international integration of Chinese society and economy requires qualified personnel with high proficiency of English. The cultivation of personnel of the "Speciality + English" type or "English + speciality" type is the ultimate goal that college English is supposed to achieve.

The history of foreign language education in China shows that the cultivation of "Speciality + English" talents is the ultimate stage of the development of foreign language education, which can be justified by Russian teaching in China after liberation. Upon liberation, many colleges and universities began to teach Russian in response to the urgent demand of the society. Special schools were set up to train Russian interpreters and Russian teachers. The Seven-Year Foreign Language Education Program promulgated in 1964 put forward the idea that education for foreign language majors should develop side by side with foreign language education for students of other specialities. On the one hand, foreign language schools and foreign language departments in institutions of higher learning should continue to cultivate foreign language specialists; on the other hand, effective measures would have to be taken to enhance the development of foreign language education in secondary schools and foreign language education for other majors except majors of foreign languages so as to cultivate a large number of specialists with scientific knowledge and a certain level of foreign language proficiency, meeting the various demands of the country (Fu, 1986, p. 77). We can clearly see, from this period of Russian teaching, that the developmental route of foreign language education is as follows: majors of foreign languages $\rightarrow$ foreign languages for other specialities $\rightarrow$ "specialty + foreign language" or "foreign language + speciality."

After the Cultural Revolution, the development of science and education became crucial to the country's modernization. Foreign language education in China could not meet the demand for specialists who knew a foreign language, especially English. English teaching for non-English majors was the great concern of the society. Secondary schools and institutions of higher learning were in great need for English teachers, and specialists and experts who knew English were badly needed in all strata of society. Many institutions of higher learning enrolled English majors in response to the needs of the society, in hopes of sending qualified English specialists to where they are needed. These specialists went to various institutions of higher learning and secondary schools as teachers of English, and to different parts of the society as translators or interpreters, who furthered their knowledge in their special field and became "English + speciality" professional translators and interpreters. Some of these English graduates worked as teachers in institutions of higher learning, teaching English to non-English majors, where courses for English majors and non-English majors are different and separate from each other, and English teachers belonged in different units of the same department. However, with the improvement of the college students' English proficiency and the increase of teachers of different specialities who had studied abroad, especially in English-speaking countries, the age of bilingual education has come. It will become the main steam of English teaching for non-English majors, and take over the mission of training "speciality + English" specialists. The result of improvement and popularization of English education in China is that English major graduates are no longer needed to take on the jobs that should have been done by graduates of other specialities. Graduates of the "speciality + English" type enjoy advantages over those of the "English + speciality" type as far as the chances of employment are concerned. The shrinking job market makes the English specialty return to its original place in the English education system, specializing in the area of the "English language and literature". Some relevant courses may be offered to English majors, but do not try to compete with bilingual courses.

The advent of English in primary schools has an impact not only on college English, but also on every sector of the English teaching and learning community. The downward focus of the English education system also means the downward flow of English teachers. The problem of transferring and training English teachers for primary schools is not easy to be dissolved. The inadequacy of primary English teachers has been hindering the overall development of English education in China. It is hoped that with the shrinking job market for English major graduates, they will be encouraged, or forced, to work at primary schools. Then, and only then, we will witness real burgeoning growth of 
English education in China.

\section{References}

China Education Misnistry. (2001). New English Curriculum (Experimental Version). Beijing: Beijing Normal University Press.

Fu, Ke. (1986). Foreign Language Education History in China. Shanghai: Shanghai Foreign Education Press.

Yang Zhenning teaches physics to freshmen at Tsinghua University. (2004, September 16). Beijing Youth. [Online] Available: http://tech.sina.com.cn/d/2004-09-16/0746426090.shtml. 